\title{
PENGARUH SENSE OF HUMOR GURU DAN PENGELOLAAN KELAS TERHADAP PRESTASI BELAJAR EKONOMI SISWA KELAS XI SMA SWASTA RAKSANA MEDAN T.P 2015/2016
}

\author{
Randeska Manullang 1), Lidia Aprileny Hutahaean 2) \\ 1) Fakultas Ekonomi, Universitas Negeri Medan \\ 2) Fakultas Ekonomi, Universitas Negeri Medan
}

\begin{abstract}
Penelitian ini dilaksanakan di SMA Swasta Raksana Medan yang beralamat di Jalan Gajah Mada, No 20. Populasi dalam penelitian ini adalah seluruh siswa kelas XI-IPS di SMA Swasta Raksana Medan T.P. 2015/2016. Teknik pengambilan sampel yang digunakan dalam penelitian ini adalah total sampling, yaitu seluruh anggota populasi sebanyak 89 siswa dijadikan sebagai sampel. Hasil yang diperoleh pada uji $\mathrm{F}$ menunjukkan bahwa terdapat pengaruh yang positif dan signifikan secara simultan variabel sense of humor guru dan pengelolaan kelas terhadap prestasi belajar ekonomi siswa kelas XI SMA Swasta Raksana Medan T.P. 2015/2016 dengan nilai Fhitung>Ftabel (89,053>3,10). Berdasarkan hasil penelitian dapat disimpulkan bahwa sense of humor guru dan pengelolaan kelas berpengaruh terhadap prestasi belajar ekonomi siswa kelas XI SMA Swasta Raksana Medan T.P. 2015/2016.
\end{abstract}

Keywords: Sense Of Humor Guru, Pengelolaan Kelas, Dan Prestasi Belajar 


\section{PENDAHULUAN}

Pendidikan dan pengajaran adalah suatu proses yang sadar tujuan. Maksudnya bahwa proses pembelajaran merupakan suatu peristiwa yang terikat, terarah pada tujuan dan dilaksanakan untuk mencapai tujuan. Proses belajar-mengajar dikatakan baik jika proses tersebut dapat membangkitkan kegiatan belajar yang efektif. Kesuksesan pengajaran bisa dilihat dari hasilnya, tetapi harus tetap diperhatikan juga prosesnya. Proses yang baik dan benar kemungkinan besar akan memberikan hasil yang baik pula.

Selain memberikan sisipan humor yang baik pada saat proses belajar mengajar berlangsung, hal yang tidak kalah penting dalam mencapai tujuan pembelajaran adalah pengelolaan kelas.. Untuk menerapkan terciptanya prestasi belajar yang optimal, guru sangat berperan penting. Seorang guru sangat diharapkan untuk melengkapi dirinya dengan berbagai keterampilan yang diharapkan dapat membantu dan menjalankan tugasnya dengan baik. Namun harapan ini masih jauh dari kenyataan yang ada di lapangan. Masih banyak guru yang belum memiliki keterampilan tersebut, baik keterampilan dalam pengelolaan kelas dan menyisipkan humor dalam proses pembelajaran. Hal tersebut terjadi karena beberapa faktor yaitu kurangnya pelatihan yang diberikan kepada guru untuk menambah keterampilan yang ia miliki dan masih kurangnya kesadaran pada guru yang hanya sekadar menginformasikan sejumlah pengetahuan yang telah ditetapkan oleh kurikulum tanpa memperhatikan pemahaman yang didapatkan oleh peserta didik.

Sekolah SMA Swasta Raksana Medan belum memperhatikan pengaturan ruangan belajar yang dapat mendukung prestasi siswa. Komponen-komponen penataan ruang belajar yang kurang mendapat perhatian seperti pengaturan tempat duduk, penataan keindahan dan kebersihan kelas, ventilasi dan tata cahaya. Kemudian ketika dilakukan pengamatan di dalam kelas pada proses belajar-mengajar, penulis melihat keterampilan dasar mengajar guru masih belum memadai. Hal ini dapat dilihat dari sikap guru yang monoton saat mengajar, ruangan kelas yang kurang kondusif saat proses belajar-mengajar berlangsung, guru kurang peduli dengan sikap siswa, sehingga tidak terjadi interaksi belajar-mengajar yang baik. Guru selalu menggunakan formasi tempat duduk dengan posisi berbaris ke belakang, tidak pernah mengubah formasi tempat duduk muridnya, seperti posisi berhadapan, posisi setengah lingkaran, atau berbentuk letter U. Selain itu guru masih mengandalkan metode ceramah dalam mengajar, guru tidak menggunakan alat peraga/media pembelajaran, belum mampu memodifikasi materi yang tidak menarik menjadi menarik, serta tidak adanya sisipan humor yang tentunya dapat membangkitkan semangat siswa dan dapat menarik perhatian siswa pada saat menyampaikan materi pembelajaran. Hal ini menyebabkan siswa merasa bosan dan mengantuk di dalam kelas, melamun, dan mulai mengambil aktivitas sendiri. Peneliti kerap kali melihat murid bersikap acuh tak acuh terhadap materi pembelajaran yang disampaikan oleh guru pada saat proses belajar-mengajar sehingga tujuan pembelajaran pun sulit untuk dicapai.

\section{METODE PENELITIAN}

Penelitian ini dilaksanakan di SMA Swasta Raksana Medan yang beralamat di Jalan Gajah Mada, No 20. Populasi dalam penelitian ini adalah seluruh siswa kelas XI-IPS di SMA Swasta Raksana Medan T.P. 2015/2016. Teknik pengambilan sampel yang digunakan dalam penelitian ini adalah total sampling, yaitu seluruh anggota populasi sebanyak 89 siswa dijadikan sebagai sampel. Uji instrumen menggunakan uji validitas dan reliabilitas angket. Uji asumsi klasik menggunakan uji normalitas dan uji linearitas. Teknik analisis data dalam penelitian ini menggunakan analisis regresi berganda, uji hipotesis parsial (uji t), uji hipotesis simultan (uji f) dan koefisien determinasi (R2).

\section{HASIL DAN PEMBAHASAN}

Sebelum penelitian dilaksanakan, angket sebagai instrument penelitian terlebih dahulu diuji. Validitas tes diuji dengan menggunakan product moment dengan hasil dari masingmasing variabel sense of humor guru dan pengelolaan kelas dinyatakan 25 soal valid. Reliabilitas tes diuji dengan menggunakan rumus alpha cronbach dengan hasil untuk reliabilitas sense of humor guru adalah sebesar $0,723>0,294$ (rhitung $>$ rtabel) dan untuk pengelolaan kelas sebesar $0,706>0,294$ (rhitung $>$ rtabel).

Analisis data untuk menguji hipotesis dengan uji t menunjukkan nilai thitung variabel 
sense of humor guru adalah sebesar 7,321. Sedangkan untuk ttabel pada taraf signifikan 95\% atau alpha 5\% adalah bernilai 1,663 sehingga thitung $>$ ttabel $(7,321>1,663)$. Maka berdasarkan kriteria pengujian hipotesis secara parsial dapat disimpulkan bahwa variabel sense of humor guru memiliki pengaruh yang positif dan signifikan terhadap prestasi belajar ekonomi siswa kelas XI SMA Raksana Medan T.P. 2015/2016.

Analisis data untuk menguji hipotesis dengan uji $\mathrm{t}$ untuk variabel pengelolaan kelas diperoleh nilai thitung sebesar 5,327 dan ttabel bernilai 1,663 sehingga thitung $>$ ttabel (5,327>1,663). Maka berdasarkan kriteria pengujian hipotesis secara parsial dapat disimpulkan bahwa variabel pengelolaan kelas memiliki pengaruh yang signifikan terhadap prestasi prestasi belajar ekonomi siswa kelas XI SMA Swasta Raksana Medan T.P. 2015/2016.

Hasil uji koefisien regresi secara bersama-sama (uji F) diperoleh Fhitung >Ftabel dimana angka signifikan penelitian diperoleh 89,053 dan Ftabel sebesar 3,10 pada taraf signifikansi 95\% ( $\alpha=5 \%)$ dan derajat kebebasan (dk) adalah (n-k-1) yaitu 89-2-1 = 86. Oleh karena nilai Fhitung $>$ Ftabel $(89,053>3,10)$ maka dapat disimpulkan bahwa ada pengaruh yang positif dan signifikan secara simultan antara sense of humor guru dan pengelolaan kelas terhadap prestasi belajar ekonomi siswa kelas XI SMA Swasta Raksana Medan T.P. 2015/2016.

Dari hasil penelitian dan pengolahan data diperoleh nilai koefisien determinasi (R2) sebesar 0,674, nilai ini memberikan arti bahwa presentase sumbangan pengaruh variabel independen yaitu sense of humor guru dan pengelolaan kelas terhadap variabel dependen prestasi belajar sebesar $67,4 \%$ sedangkan sisanya $32,6 \%$ dipengaruhi oleh variabelvariabel lain yang berada di luar analisa penelitian ini.

Setelah dilakukan analisis regresi linear berganda yaitu untuk mengukur pengaruh antara variabel sense of humor guru dan pengelolaan kelas terhadap prestasi belajar, didapat persamaan regresi yaitu $\mathrm{Y}=5,932+0,773$ $\mathrm{X} 1+0,432 \mathrm{X} 2$. Dimana persamaan tersebut menyatakan bahwa nilai konstanta 5,932 menunjukkan apabila variabel sense of humor guru dan pengelolaan kelas bernilai nol, maka prestasi belajar akan bertambah 5,932. Koefisien regresi variabel sense of humor guru sebesar 0,773 artinya jika variabel bebas lain nilainya tetap dan pengelolaan kelas mengalami peningkatan satu satuan, maka prestasi belajar meningkat sebesar 0,773. Koefisien regresi variabel pengelolaan kelas sebesar 0,432 artinya jika variabel bebas lain nilainya tetap dan sense of humor guru mengalami peningkatan satu satuan, maka prestasi belajar meningkat sebesar 0,432 .

\section{KESIMPULAN}

Berdasarkan data yang diperoleh dari hasil analisis pengujian dari pembahasan terhadap hasil penelitian yang telah dikumpulkan mengenai sense of humor guru dan pengelolaan kelas terhadap prestasi belajar ekonomi siswa kelas XI SMA Swasta Raksana Medan T.P. 2015/2016. Secara simultan terdapat pengaruh yang positif dan signifikan secara simultan antara sense of humor guru dan pengelolaan kelas terhadap prestasi belajar ekonomi siswa kelas XI SMA Swasta Raksana Medan T.P. 2015/2016.

\section{REFERENSI}

Abdillah, Husni. 2002. Pengertian Belajar dari Berbagai Sumber. http://husniabdillah.multiply.comlioumal/i tem/9 (26 Februari 2016)

Afriyanti, Nova. 2015. Hubungan antara Sense of Humor Guru dengan Interaksi Edukatif pada Siswa Kelas XI SMA Negeri 10 Palembang. Jurnal Fakultas Psikologi Universitas Bina Darma Palembang. http://digilib.binadarma.ac.id/files/disk1/1 33/123-123-novaafriya-6645-1-jurnal.pdf (21 Februari 2016)

Arikunto, Suharsimi. 2006. Prosedur Penelitian Sebuah Pendekatan. Jakarta: Rineka Cipta.

2010. Prosedur Penelitian Sebuah Pendekatan. Jakarta: Rineka Cipta.

Azzet, Akhmad Muhaimin. 2011. Menjadi Guru Favorit. Yogyakarta: Ar-Ruzz Media.

Darmansyah. 2011. Strategi Pembelajaran Menyenangkan dengan Humor. Jakarta: Bumi Aksara.

Djamarah, Syaiful Bahri dan Aswan Zain. 2006. Strategi Belajar Mengajar. Jakarta: Rineka Cipta.

Djamarah, Syaiful Bahri. 2005. Guru dan Anak Didik dalam Interaksi Edukatif. Jakarta: Rineka Cipta.

Hadis, Abdul. 2006. Psikologi dalam Pendidikan. Bandung: Alfabeta. 
Hafzah. 2014. Hubungan Sense of Humor Guru dalam Mengajar di Kelas dengan Motivasi Belajar Siswa di SMA Negeri Sangatta Utara. Jurnal Psikologi Volume 2 Nomor 1 FISIP UNMUL. http://ejournal.psikologi.fisipunmul.ac.id/site/wpcontent/uploads/2014/03/Jurnal\%20\%280 3-05-14-06-05-32\%29.pdf (21 Februari 2016)

Hamdani. 2011. Strategi Belajar Mengajar. Bandung: Pustaka Setia.

Ismail, DP. 2009. Kurikulum dan Pembelajaran. Yogyakarta: Grha Guru.

Kandoli, Louisa Nicolina. 2011. Motivasi dan Hubungannya dengan Prestasi Belajar Mahasiswa pada Mata Kuliah Tata Hidang di Jurusan PKK Fakultas Teknik Universitas Negeri Manado. Jurnal Pendidikan Teknologi dan Kejuruan Volume 2 Nomor 2 ISSN 2087-3581. https://jurnaledvokasi.files.wordpress.com /2012/02/11_98-104-vol-2-no-2-2011motivasi-dan-hubungannya-denganprestasi-belajar-mahasiswa-pada-matakuliah-tata-hidang-di-jurusan-pkkfakultas-teknik-universitas-negerimanado-kandoli.pdf (5 Maret 2016)

Khanifatul. 2013. Pembelajaran Inovatif. Yogjakarta: Ar-Ruzz Media.

Khodijah, Nyayu. 2014. Psikologi Pendidikan. Jakarta: Rajawali Pers.

Kristiandi. 2009. Hubungan Persepsi Siswa terhadap Sense of Humor Guru dengan Motivasi Belajar di Kelas 7 Internasional Sekolah Menengah Pertama Negeri 1 Medan. Universitas Sumatera Utara. http://repository.usu.ac.id/bitstream/12345 6789/14516/1/09E01122.pdf (21 Februari 2016)

Latif, Azhar Azelina. 2012. Defenisi Pengertian dan Faktor-Faktor yang Mempengaruhi Prestasi Belajar. https://azharm2k.wordpress.com/2012/05/ 09/definisi-pengertian-dan-faktor-faktoryang-mempengaruhi-prestasi-belajar/ (26 Februari 2016)

Manik, Borris Power. 2014. Pengaruh Pengelolaan Kelas Terhadap Prestasi Belajar Ekonomi Siswa Kelas XI IPS SMA RK Deli Tua Tahun Ajaran 2013/2014. Universitas Negeri Medan.

Mulyati. 2005. Psikologi Belajar. Yogyakarta: Andi Offset.
Novalin, Elsa Tiana. 2015. Pengaruh Sense of Humor Guru dalam Mengajar di Kelas dan Motivasi Belajar Terhadap Prestasi Belajar Ekonomi Siswa Kelas X di SMA Swasta Budisatrya Medan T.A. 2014/2015. Universitas Negeri Medan.

Parman, Rahmawaty. 2013. Penyesuaian Diri Laki-laki dan Perempuan dengan Mengendalikan Variabel Sense of Humor. Jurnal Online Psikologi Volume 01 Nomor $02 \quad$ ISSN 2301-8259. http://ejournal.umm.ac.id/index.php/jop/ar ticle/view/1653/1749 (5 Maret 2016) 